\title{
POTENSI PEMANFAATAN LIMBAH PERTANIAN LOKAL SEBAGAI PUPUK ORGANIK CAIR TERHADAP PERTUMBUHAN DAN PRODUKSI PETSAI (Brassica pekinensis)
}

\section{Potential Use of Local Agricultural Waste as Organic Liquid Fertilizer on Growth and Production of Petsai (Brassica Pekinensis)}

\author{
Dessy A Marasabessy*, Vilma L. Tanasale \\ Jurusan Budidaya Pertanian, Fakultas Pertanian, Universitas Pattimura \\ *Korespondensi penulis: e-mail desimarasabessy79@gmail.com
}

Diterima: Februari 2020

Disetujui terbit: Desember 2020

\begin{abstract}
Local agricultural waste in the environment (in-situ) can be used as liquid organic fertilizer to support the growth and production of petsai (Brassica pekinensis). This study aimed to examine the potential of local agricultural waste (tubers and banana peels, Colopogonium mucunoides weed, rice water, and coconut water as liquid organic fertilizer on the growth and production of petsai. This research was conducted at Tulehu Village, Salahutu District, Central Maluku Regency from August to November 2018. The experiment used randomized block design with one factor. The treatment used in this study was the dose of liquid organic fertilizer consisting of 4 levels: control (P0), $10 \mathrm{ml} / \mathrm{L}^{-1}$ (P1), $20 \mathrm{ml} \mathrm{L}^{-1}$ (P2), $30 \mathrm{ml} \mathrm{L}^{-1}(P 3)$. Data was analyzed using ANOVA. If there was significant influence will be continued with $B N J$ level of $5 \%$. The results showed that the dose of liquid organic fertilizer significantly affected plant height, number of leaves, plant fresh weight and plant dry weight but did not significantly affect leaf area. A dose of $20 \mathrm{ml} \mathrm{L}^{-1}$ of water showed a significant effect on plant height and leaf number of $38.21 \mathrm{~cm}$ and 18.79 respectively compared to other treatments. $P 2$ treatment $\left(20 \mathrm{ml} \mathrm{L}^{-1}\right)$ showed a significant effect on plant fresh weight (140.12) $g$ and plant dry weight (28.73) $g$ when compared with other treatments.

Keywords: banana peels and tuber, coconut water, Colopogonium mucunoides, petsai, rice water.
\end{abstract}

\begin{abstract}
ABSTRAK
Limbah pertanian lokal yang terdapat di sekitar lingkungan (in-situ) dapat dimanfaatkan sebagai pupuk organik cair untuk menunjang pertumbuhan dan produksi tanaman petsai (Brassica pekinensis). Penelitian ini bertujuan untuk mengkaji potensi limbah pertanian lokal (bonggol pisang, kulit pisang, gulma Colopogonium mucunoides, air beras, dan air kelapa) sebagai pupuk organik cair terhadap pertumbuhan dan produksi tanaman petsai. Penelitian ini dilaksanakan di Desa Tulehu, Kecamatan Salahutu, Kabupaten Maluku Tengah dari Bulan Agustus-November 2018. Penelitian dilakukan dengan menggunakan Rancangan Acak Kelompok dengan satu faktor. Perlakuan yang digunakan dalam penelitian adalah dosis pupuk organik cair terdiri atas 4 taraf yaitu: kontrol (P0), $10 \mathrm{ml} \mathrm{L}^{-1}$ (P1), $20 \mathrm{ml} \mathrm{L}^{-1}$ (P2), $30 \mathrm{ml} \mathrm{L}^{-1}$ (P3). Analisis data menggunakan ANOVA bila berpengaruh nyata akan dilanjutkan dengan BNJ taraf $5 \%$. Hasil penelitian menunjukkan bahwa dosis pupuk organik cair berpengaruh nyata terhadap tinggi tanaman, jumlah daun, bobot segar dan bobot kering tanaman tetapi tidak berpengaruh nyata terhadap luas daun. Dosis $20 \mathrm{ml} \mathrm{L}^{-1}$ menunjukkan pengaruh nyata terhadap tinggi tanaman dan jumlah daun masingmasing $38,21 \mathrm{~cm}$ dan 18,79 bila dibandingkan perlakuan lainnya. Perlakuan P2 $\left(20 \mathrm{ml} \mathrm{L}^{-1}\right)$ menunjukan pengaruh nyata terhadap bobot segar tanaman 140,12 g dan bobot kering tanaman $28,73 \mathrm{~g}$ bila dibandingkan dengan perlakuan lainnya.

Kata Kunci: air beras, air kelapa, bonggol dan kulit pisang, Colopogonium mucunoides, petsai
\end{abstract}




\section{PENDAHULUAN}

Petsai (Brassica Pekinensis) merupakan tanaman sayuran daun dari keluarga Cruciferae yang memiliki nilai ekonomis tinggi dan cocok untuk dikembangkan di daerah sub tropis maupun tropis. Petsai diduga berasal dari Tiongkok (Cina) dan Asia Timur. Tanaman ini telah dibudidayakan sejak 2.500 tahun yang silam kemudian menyebar ke Filipina dan Taiwan. Tanaman tersebut memiliki banyak sekali manfaat, di antaranya adalah untuk menyehatkan mata, menurunkan kolesterol, menghindari serangan jantung, sumber vitamin, dan makanan untuk memulihkan tenaga. Hal ini dikarenakan petsai memiliki kadar zat besi yang tinggi dan mengandung magnesium (Hernowo, 2010). Salah satu faktor yang berperan penting dalam meningkatkan produktivitas dan nilai gizi pada tanaman petsai dengan pemupukan. Pupuk merupakan bahan organik maupun bahan anorganik yang berfungsi memberikan unsur hara bagi tanaman untuk pertumbuhan dan perkembangannya.

Limbah pertanian adalah sisa dari proses produksi pertanian yang dapat di gunakan sebagai potensi pupuk organik padat maupun pupuk organik cair. Limbah pertanian antara lain dapat berupa limbah tanaman pangan, limbah tanaman perkebunan, dan kotoran ternak. Hasil penelitian Nurhayati et al. (2011), di Kabupaten Kampar potensi limbah hasil pertanian sebagai pupuk organik berupa sisa hasil tanaman pangan 40.930 t/tahun, tanaman perkebunan $74.840 \mathrm{t} /$ tahun, dan limbah ternak $17.612 \mathrm{t}$ tahun. Pupuk organik mengandung hara makro dan mikro yang lengkap meskipun kandungan unsur haranya sedikit. Penggunaan pupuk organik secara terus-menerus dalam rentang waktu tertentu akan menjadikan kualitas tanah lebih baik dibandingkan dengan hanya menggunakan pupuk anorganik. Hasil penelitian Muhsin (2011), pupuk organik yang dibuat dari hasil pengolahan tebu berupa limbah tebu, kandungan unsur hara yaitu: fosfor $(P)$ 1,57\%, nitrogen (N) 0,93\%, dan kalium (K) 0,30\%. Hasil penelitian Shaleh (2017) menyatakan bahwa interaksi pemberian sabut kelapa dan ekstrak tauge sebagai pupuk organik cair memberikan pengaruh terhadap tinggi tanaman, berat basah, dan kandungan protein petsai. Pupuk organik cair adalah larutan dari hasil pembusukan bahan organik yang 
berasal dari sisa tanaman, limbah agroindustri, kotoran hewan, dan kotoran manusia yang memiliki kandungan lebih dari satu unsur hara (Hidayati, 2013).

Limbah pertanian yang tersedia banyak di lingkungan sekitar seperti kulit pisang, bonggol pisang, gulma daun kacang-kacang (Colopogonium mucunoides), air beras, dan air kelapa. Hasil penelitian Suhastyo (2011), bonggol pisang mengandung mikroba pengurai bahan organik dan karbohidrat (66\%), protein, air, dan mineral-mineral penting. Bonggol pisang mempunyai kandungan pati $45,4 \%$ dan kadar protein $4,35 \%$. Air kelapa mengandung gula dan juga mikromineral yang bermanfaat sebagai sumber nutrisi untuk jamur. Solihin (2012) air kelapa di dalamnya mengandung hormon-hormon yang membantu menstimulir pertumbuhan dan perkembangan jaringan, seperti auksin, sitokinin, dan giberelin. Selain air kelapa, kandungan vitamin B1, B12, fosfor, nitrogen dan karbohidrat yang terkandung dalam air beras dapat digunakan sebagai sumber pupuk organik cair. Adapun kandungan yang terdapat di kulit pisang yakni protein, kalsium, fosfor, magnesium, sodium dan sulfur, sehingga kulit pisang memiliki potensi yang baik untuk dimanfaatkan sebagai pupuk organik (Susetya, 2012).

Gulma Colopogonium mucunoides merupakan jenis leguminosa yang banyak digunakan sebagai pupuk hijau Tanaman legum relatif mudah terdekomdosisi sehingga penyediaan haranya menjadi lebih cepat. Hasil penelitian Farni et al. (2011), pemberian Colopogonium mucunoides dan Pueraria javanica 5 dan 10 ton/ha mampu meningkatkan hasil kedelai dan hasil tinggi dicapai pada pemberian Calopogonium mucunoides 10 toh/ha yaitu $258,12 \mathrm{~kg} / \mathrm{ha}$.

Pembuatan pupuk organik cair membutuhkan mikroorganisme yang berperan mempercepat proses fermentasi limbah organik, mikroorganisme ini disebut Effective Microorganism 4 (EM4). Fungsinya adalah mempercepat penguraian bahan organik, menghilangkan bau yang timbul selama proses penguraian, menekan pertumbuhan mikroorganisme patogen, dan meningkatkan aktivitas mikroorganisme yang menguntungkan.

Penelitian ini bertujuan untuk mengkaji potensi limbah pertanian local sebagai pupuk organik cair terhadap pertumbuhan dan produksi tanaman petsai. Penelitian ini diharapkan sebagai 
sumber pengetahuan dalam pemanfaatan limbah pertanian yang tersedia di lingkungan sekitar sebagai pupuk organik cair terhadap pertumbuhan dan produksi tanaman petsai, untuk mengatasi masalah pencemaran lingkungan.

\section{METODE}

Penelitian ini dilaksanakan pada Lahan Desa Tulehu Kecamatan Salahutu Kabupaten Maluku Tengah dari Agustus-November 2018. Bahan yang digunakan adalah benih petsai, kulit pisang, batang pisang, daun kacang-kacang (Colopogonium mucunoides), gula merah, air kelapa, air beras, EM4, dan polibag, tanah kambisol, bambu, plastik meter, dan jaring pelindung tanaman. Alat yang digunakan adalah tong air, gen ukuran 5 liter, kotak penyemaian, timbangan, gembor, cangkul, rollmeter, sabit, parang, plastik meter, ember, sprayer, selotip, sarung tangan, masker, kamera, handsprayer, selang kecil (selang tukang), dan alat tulis menulis.

Data diolah
menggunakan
Kelompok dengan satu faktor. Perlakuan

yang digunakan adalah dosis pupuk organik cair terdiri atas 4 taraf yaitu: kontrol (P0), $10 \mathrm{ml} / 1$ liter air (P1), $20 \mathrm{ml} /$ 1liter (P2), $30 \mathrm{ml} / \mathrm{l}$ air (P3).

Tahap awal penelitian adalah melakukan inventarisasi limbah pertanian sekitar untuk dijadikan sebagai pupuk organik cair dilanjutkan dengan pengujian pupuk organik cair terhadap pertumbuhan dan produksi petsai. Bibit petsai yang berumur 2 minggu di pindahkan ke polybag yang telah berisi tanah dan bokashi dengan perbandingan 3:1. Polibag yang digunakan berukuran 30x15 cm dengan berat tanah tiap polibag adalah $4 \mathrm{~kg}$. Polibag ditempatkan dalam rumah plastik sesuai perlakuan dengan luas $8 \times 4 \mathrm{~m}$, tinggi rumah plastic $2,5 \mathrm{~m}$ dan ukuran plastik adalah 50×150 m. Pemberian pupuk organik cair dilakukan pada hari ke 4, 8, 12,16, 20, dan 24 hari setelah pindah lapang dan diberikan dalam volume yang sama setiap perlakuan sebanyak $250 \mathrm{ml}$. Selain pemberian pupuk organik cair Pemeliharaan tanaman berupa penyiraman, penyiangan gulma, serta pengendalian OPT. Penyiraman air dilakukan pagi dan sore dengan volume yang sama tiap tanaman sebanyak 500 ml. Pengendalian OPT menggunakan 
pestisida nabati yaitu gulma babandotan sebanyak $500 \mathrm{~g}$ dihaluskan dan direndam dalam satu liter air, kemudian dibiarkan selama 24 jam. Hasil rendaman disaring dan ditambahkan sabun cair sebanyak $5 \mathrm{ml}$ kemudian disemprotkan pada tanaman yang terserang. Parameter yang diamati meliputi tinggi tanaman, jumlah daun, luas daun, bobot segar tanaman, dan bobot kering tanaman. Analisis data dari peubah yang diamati, dilakukan dengan menggunakan analisis varians dan apabila terdapat pengaruh nyata dilanjutkan dengan uji BNJ pada taraf $5 \%$.

\section{HASIL DAN PEMBAHASAN}

\section{Pembuatan Pupuk Organik Cair} Berbasis Limbah Pertanian Lokal

Pembuatan Pupuk Organik cair ini dilakukan dengan cara fermentasi dengan bantuan bioaktivaktor EM4 untuk mempercepat pengomposan. Bahan yang digunakan adalah daun kacang-kacangan, bonggol pisang, limbah kulit pisang, air beras dan air kelapa, dan gula merah.
Tahap-tahap pembuatan pupuk organik cair:

a) Bonggol pisang, kulit pisang, daun kacang-kacang

(Colopogonium mucunoides), dicacah menjadi bagian yang lebih kecil atau dapat menggunakan mesin pemarut

b) Limbah bahan organik tersebut dimasukan kedalam tong air plastik kemudian ditambahkan air beras, air kelapa, EM4, dan gula merah

c) Bahan-bahan yang sudah dimasukkan seluruhnya ke dalam tong kemudian diaduk sampai tercampur rata (homogen).

d) Penutup tong dilubangi sebagai tempat masuk selang yang dihubungkan dengan gen yang berisi air untuk menyalurkan panas yang dihasilkan dari proses fermentasi.

e) Pupuk organik cair dikontrol dua hari sekali penutup tong yang berisi bahan organik tersebut dibuka dan diaduk atau dibolak-balik agar terjadi pertukaran udara di dalam tong yang berisi bahan organik sehingga mikroorganisme dapat tetap hidup dan melakukan proses fermentasi.

f) Pupuk organik cair yang telah matang tidak berbau busuk, bahan telah terurai sempurna, bau khas tape. 
Proses pembuatan Pupuk Organik Cair dapat dilihat pada Gambar 1. Beberapa faktor yang dapat mempengaruhi proses pembuatan pupuk organik cair adalah $\mathrm{C} / \mathrm{N}$ bahan organik, ukuran bahan, campuran bekerja, kelembaban dan aerasi, kemasaman $(\mathrm{pH})$, dan temperatur (Indriani, 2011).
Proses fermentasi akan berlangsung bila mikroorganisme bekerja dengan baik bila kondisi sesuai yaitu $\mathrm{pH}$ rendah (3-4), kadar garam dan kadar gula tinggi, suhu sekitar $40-50{ }^{\circ} \mathrm{C}$ (Indriani, 2011).

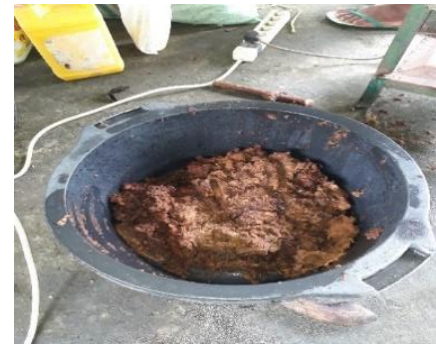

A

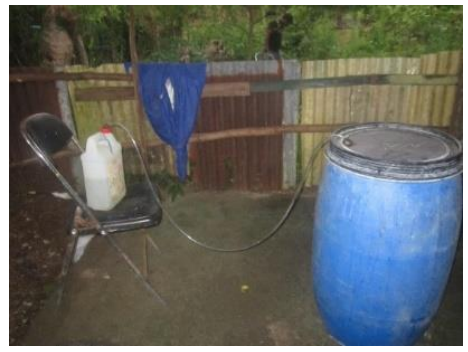

B

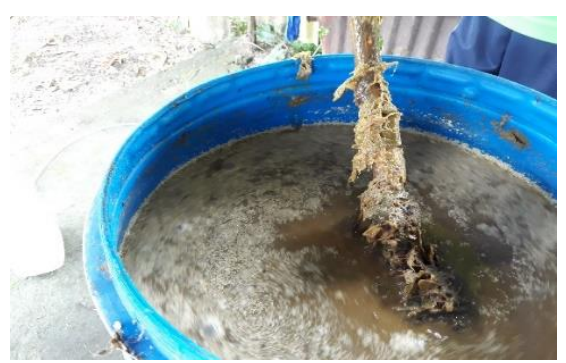

C

Gambar 1 Proses pengolahan limbah organik (A) Pencacahan, (B) Fermentasi,

(C) Perubahan kondisi fisik bahan (terdapat miselia putih (jamur)

\section{Respon Pertumbuhan dan Produksi} Tanaman Petsai

Hasil sidik ragam menunjukan bahwa dosis pemberian POC berpengaruh nyata pada parameter pertumbuhan dan produksi tanaman petsai: tinggi tanaman, jumlah daun, bobot segar tanaman, dan bobot kering tanaman, tetapi dosis pemberian pupuk organik cair tidak berpengaruh nyata terhadap parameter luas daun (Tabel 1).

\section{Tinggi Tanaman dan Jumlah Daun}

Hasil sidik ragam menunjukkan bahwa dosis pemberian Pupuk Organik Cair berpengaruh nyata terhadap tinggi tanaman dan jumlah daun. Perlakuan P2 menunjukkan tinggi tanaman nyata lebih tinggi bila dibandingkan dengan perlakuan lainnya. Perlakuan P0 dan P1 menunjukkan hasil yang tidak tidak berbeda nyata. Tanaman tertinggi terletak pada perlakuan P2 adalah 38,21 $\mathrm{cm}$. 
Paramater jumlah daun menunjukan masing-masing perlakuan berbeda nyata dengan perlakuan lainnya. Jumlah daun tertinggi pada perlakuan P2 yaitu 18,79 helai. Hasil uji beda rataan tinggi tanaman dan jumlah daun dapat dilihat pada Tabel 2 . Perlakuan P2 (20 ml/L air) memberikan hasil tertinggi pada tinggi tanaman dan jumlah daun jika dibandingkan dengan perlakuan lainnya. Hal ini diduga dosis $20 \mathrm{ml} / \mathrm{L}$ air dapat mencukupi kebutuhan tanaman dalam melakukan proses metabolisme. Hipotesis ini didukung oleh hasil penelitian Hairuddin dan
Mawardi (2015) yang menyatakan bahwa pemberian pupuk organik air cucian beras dosis $20 \mathrm{ml} / \mathrm{L}$ air pada tanaman sawi menunjukan nyata pada tinggi tanaman 33,18 cm dan nyata pada jumlah daun tertinggi 16,22 helai dibandingkan dengan perlakuan lainnya pada akhir pengamatan (28 HST). Pupuk organik cair dengan kombinasi air kelapa, kotoran ayam, dan daun gamal memberikan pengaruh nyata terhadap tinggi tanaman dan jumlah daun masingmasing 33,67 cm dan 23 helai pada tanaman sawi umur 30 HST (Febrianna et al. 2018).

Tabel 1 Rekapitulasi hasil sidik ragam komponen pertumbuhan dan produksi tanaman petsai

\section{Parameter}

Tinggi Tanaman $(\mathrm{cm})$
Jumlah Daun
Luas Daun
Bobot segar tanaman $(\mathrm{g})$
Berat kering tanaman $(\mathrm{g})$
Keterangan: * Berpengaruh nyata
Bobot Segar dan Bobot Kering
Tanaman

Analisis sidik ragam menunjukkan bahwa perlakuan dosis pupuk organik cair memberikan pengaruh nyata terhadap parameter bobot segar dan bobot kering tanaman. Bobot segar tanaman perlakuan $\mathrm{P} 0, \mathrm{P} 1, \mathrm{P} 2$ dan $\mathrm{P} 3$
Sidik Ragam

tn 
Tabel 2 Uji beda rataan tinggi tanaman petsai dan jumlah daun pada perlakuan dosis pemberian POC (4 MST)

\begin{tabular}{ccc}
\hline Perlakuan & Tinggi Tanaman $(\mathbf{c m}$ & Jumlah Daun (helai) \\
\hline P0 & $19,39^{\mathrm{cd}}$ & $10,19^{\mathrm{d}}$ \\
P1 & $21,45^{\mathrm{c}}$ & $13,23^{\mathrm{c}}$ \\
P2 & $38,21^{\mathrm{a}}$ & $18,79^{\mathrm{a}}$ \\
P3 & $34,33^{\mathrm{b}}$ & $16,57^{\mathrm{b}}$ \\
\hline
\end{tabular}

Keterangan: Angka-angka yang diikuti oleh huruf yang sama pada kolom yang sama menunjukkan tidak berbeda nyata pada taraf nyata 0,05

Analisis sidik ragam untuk ratarata berat segar dan berat kering tanaman tanaman petsai dapat dilihat pada Tabel 3. Data bobot segar dan bobot kering tanaman yang diperoleh menunjukkan perbedaan yang nyata di antara perlakuan dosis pupuk organik cair. Selain itu, terdapat kecenderungan semakin tinggi dosis POC yang diberikan sampai dosis $20 \mathrm{ml} / \mathrm{l}$ air maka menghasilkan bobot segar tanaman dan bobot kering tanaman tertinggi yaitu masing-masing 140, $22 \mathrm{~g}$, dan 28,73 g. namun bila dosis ditingkatkan menjadi $30 \mathrm{ml} / \mathrm{l}$ air maka hasilnya akan menurun. Hal ini didukung oleh Marpaung et al. (2017) yang menyatakan bahwa pemberian POC $20 \mathrm{ml} / \mathrm{l}$ air menghasilkan bobot per tanaman (bersih dan anakan) serta produksi per plot nyata lebih tinggi dari perlakuan lainnya, yaitu masing-masing 64,50 g; $68,17 \mathrm{~g}$ dan $6,54 \mathrm{~g} \mathrm{~kg} / 2 \mathrm{~m}^{2}$ dan terdapat kecendrungan bila dosis ditingkatkan maka produksi semakin menurun.

Tabel 3 Uji Beda Rataan bobot basah tanaman dan bobot kering tanaman pada perlakuan dosis pemberian POC 30 (HST)

$\begin{array}{ccc}\text { Perlakuan } & \text { Bobot segar }(\mathbf{g}) & \text { Bobot kering } \\ \text { P0 } & 15,83^{\mathrm{d}} & 17,2^{\mathrm{d}} \\ \text { P1 } & 94,17^{\mathrm{c}} & 24,24^{\mathrm{c}} \\ \text { P2 } & 140,12^{\mathrm{a}} & 28,73^{\mathrm{a}} \\ \text { P3 } & 137,77^{\mathrm{b}} & 26,75^{\mathrm{b}}\end{array}$

Keterangan: Angka-angka yang diikuti oleh huruf yang sama pada kolom yang sama menunjukkan tidak berbeda nyata pada taraf nyata 0,05 . 
SIMPULAN DAN SARAN

\section{Simpulan}

Pemberian pupuk organik cair terhadap pertumbuhan dan produksi tanaman petsai tertinggi terdapat pada perlakuan P2 (20 ml/L air).

Pupuk Organik cair yang berasal dari limbah pertanian local dapat dimanfaatkan sebagai bahan pembuatan pupuk organik cair yang bermanfaat bagi pertumbuhan dan produksi petsai.

\section{Saran}

Perlu adanya penelitian lanjutan pada tanaman lain tentang penggunaan pupuk organik cair untuk memperoleh hasil yang optimum bagi tanaman sayuran.

\section{UCAPAN TERIMA KASIH}

Terima kasih kami sampaikan kepada Fakultas Pertanian Universitas Pattimura yang telah mendanai penelitian ini yang bersumber dari dana PNBP Fakultas.

\section{DAFTAR PUSTAKA}

Farni Y, Arsyad AR, Ermadani. 2011. Aplikasi pupuk hijau (Colopogonium mucunoides dan
Pueraria javanica) terhadap air tanah tersedia dan hasil kedelai. $J$. Hidrolitan. 2(1): 31 - 39.

Febrianna M, Prijono S, Kusumarini N. 2018. Pemanfaatan pupuk organik cair untuk meningkatkan serapan nitrogen serta pertumbuhan dan produksi sawi (Brassica juncea L.) pada tanah berpasir. Jurnal Tanah dan Sumberdaya Lahan Vol 5 No 2: 1009-1018

Hairuddin R, Mawardi R. 2015. Efektifitas pupuk organik air cucian beras terhadap pertumbuhan tanaman sawi hijau (Brassica juncea L.). Jurnal Perbal Volume 3 No.3

Hernowo. 2010. Bertanam Petsai dan Sawi. Agromedia Pusataka. Jakarta

Hidayati E. 2013. Kandungan fosfor, $\mathrm{C} / \mathrm{N}$, dan $\mathrm{pH}$ pupuk cair hasil fermentasi kotoran berbagai ternak dengan starter Stardec. Skripsi Fakultas Pendidikan Matematika dan IImu Pengetahuan Alam Program Studi Pendidikan Biologi IKIP PGRI Semarang. 
Indriani YH. 2011. Membuat Kompos Secara Kilat. Penebar Swadaya. Yogyakarta.

Jamil NA, Anggraini RS. 2011. Potensi limbah pertanian sebagai pupuk organik lokal di lahan kering dataran rendah iklim basah. Jurnal Iptek Tanaman Pangan Vol. 6 No. 2 - 2011.

Marpaung AE. 2017. Pemanfaatan jenis dan dosis pupuk organik cair (POC) untuk meningkatkan pertumbuhan dan hasil sayuran kubis. Jurnal Agroteknosains Vol. 01 No. 02

Muhsin A. 2011. Pemanfaatan limbah hasil pengolahan pabrik tebu blotong menjadi pupuk organik. Jurnal Teknik Industri -UPN Veteran. Yogyakarta Vol.1-9.

Shaleh NR. 2017. Pemanfaatan limbah sabut kelapa dan ekstrak tauge sebagai pupuk organik cair untuk meningkatkan kandungan protein dan pertumbuhan tanaman sawi.

Solihin A. 2012. Pengaruh Pemberian Air Kelapa terhadap Media Hidroponik pada Tanaman Tomat.http://ahmadsolixin.blogsp ot. com/2012/10/pengaruhpemberian-air-kelapaterhadap.html.Diakses tanggal 08 Februari 2018

Suhastyo AA. 2011. Studi mikrobiologi dan sifat kimia mikroorganisme lokal yang digunakan pada budidaya padi metode SRI (System of Rice Intensification). Tesis. Sekolah Pascasarjana. Institut Pertanian Bogor.

Susetya D. 2012. Panduan Lengkap Membuat Pupuk Organik. Penerbit Baru Press, Jakarta 
POTENSI PEMANFAATAN LIMBAH PERTANIAN LOKAL SEBAGAI PUPUK ORGANIK CAIR TERHADAP PERTUMBUHAN DAN PRODUKSI PETSAI

(Brassica pekinensis). Dessy A Marasabessy*, Vilma L. Tanasale 